ISSN 2411-4758 (Print) 2518-1602 (Online)

Native word in ethnocultural dimension, Drohobych, Posvit, 2021, pp. 152-158.

DOI: https://doi.org/10.24919/2411-4758.2021.211705

УДК 809.1

\title{
ТВОРЧІСТЬ ШЕВЧЕНКА: ФІЛОСОФІЯ ЧИ ЛІТЕРАТУРА
}

\section{Марія ЧОБАНЮК,}

кандидат філологічних наук, доцент кафедри мовної та міжкультурної комунікачії, Дрогобицький державний педагогічний університет імені Івана Франка (Україна, Дрогобич) mariya_chobanyuk@ukr.net

ORCID: http://orcid.org/0000-0002-6047-4852

Research ID X-9269-2019 http://www.researcherid.com/rid/X-9269-2019.

\section{Статтю подано до редколегіi / The article is submitted to the editorial board:}

11.09.2020.

Статтю опубліковано / The article is published: 22.02.2021.

У статті досліджено питання співвідношення філософії та літератури у творчості украӥнського генія Тараса Шевченка. Дискусія про новий статус і творчість Шевченка не вичерпана й не завершена, а щораз відновлюється 3 більшою силою.

Суттево, щуо з часів античності аж до сучасних літературних теорій не закінчується дискусія про співвідношення філософії й літератури. Думки Платона та Аристотеля вже давно стали стереотипними, проте зберігають свою гносеологічну вагомість у нових мовних іпостасях. У зв'язку з иим можемо стверджувати, щуо всі ијі роки дискусія про те, щуо література і філософія або цүілком не сумісні, або генетично споріднені, коливалась між платонівським і аристотелівським твердженнями.

Літературна спадщина Шевченка багатовекторна (лірична, епічна, драматична й прозова). Для неї характерні любовні, побутові, історичні, суспільні, політичні, релігійні, філософічні теми. Філософічна тема в більшості випадків умонтована в сюжетну будову, авторські рефлексіі, поведінку персонажів та в метатекст. Філософічна теза в багатьох випадках висловлена чітко окресленими твердженнями.

У дослідженні проаналізовано погляди відомого західного українознавия Івана Фізера щзодо розгляду фундаментальних досліджень співвідномення філософї̈ й літератури у літературній спадщині Тараса Шевченка, які знайшли своє відображення в літературознавчій $і$ критичній практиці. Іван Фізер розглядає взаємовідношення філософії творчості Шевченка за схемою Моріса Вайца. Таке взаємовідношення американський науковець трактує як три окремі проблеми, а саме: 1) філософія й література, 2) філософія літератури та 3) філософія в ліmepamypi. 
Варто наголосити, щчо літературна спадщина Тараса Шевченка стала частиною національної та загальнолюдської системи цінностей, адже пронизана великою повагою до мудрості й правди.

Ключові слова: література; філософія; критика; літературознавство; Шевченко; дискусія; текст; творчість.

\section{SHEVCHENKO CREATIVITY: PHILOSOPHY OR LITERATURE}

\section{Mariia CHOBANYUK,}

Ph.D. in Philology, Associate Professor, Department of Linguistic and intercultural communication, Drohobych Ivan Franko State Pedagogical University (Ukraine, Drohobych) mariya_chobanyuk@ukr.net

The article examines the relationship between philosophy and literature in the works of Taras Shevchenko. The discussion about the new status and work of Shevchenko is not exhaustive and not over, but from time to time flares up with new efficacy.

The study analyzes the views of Ivan Fizer on the consideration of fundamental studies of the relationship between philosophy and literature in the literary creativity of Shevchenko, which are reflected in literary and critical practice. Fizer considers the relationship between the philosophy of Shevchenko's work as three separate problems, namely: 1) philosophy and literature, 2) philosophy of literature and 3) philosophy in literature.

Taras Shevchenko's literary works has outgrown its aesthetic dimensions and become part of the national and universal system of values.

Keywords: literature; philosophy; criticism; literary studies; Shevchenko; discussion; text; creativity.

Relevance of research. From Plato and Aristotle to the literary theories of our time, the discussion of the relationship between philosophy and literature does not stop. The arguments of these two titans of human thought have long been stereotyped, but retain their epistemological significance in new linguistic guises. It can be said that for two millennia the whole debate that literature and philosophy were either completely incompatible or genetically related oscillated between the claims of Plato and Aristotle. For Plato, the literary image, three times distant from the invariant and universal reality of ideas, was only a pernicious ghost, the antithesis of unconditional truth. Aristotle, combining the timeless reality of ideas with its constant manifestation, endowed the poetic text with a generalizing truth. But this does not mean that he identified literature with philosophy.

Subject of study. Almost all subsequent debates on the relationship between philosophy and literature, were only common notes to the texts of 
Plato and Aristotle. Renaissance humanists, aesthetics of the eighteenth and nineteenth centuries joined either the views of Plato or Aristotle.

The purpose of the article. The question arises as to the reason for such a radical merger or division of these two branches of human creativity. From the arguments of both of them is their fundamentally different understanding of human mental functions. In this regard, I. Fizer (1925 - 2007, professor emeritus, one of the most prominent representatives of Ukrainian studies in the English-speaking world) notes: «Those who considered and still consider the mind a central component of the human psyche, and thus the exclusive means of truth, described philosophy as a scientific field, and literature as a kind of quasi-intellectual activity. Conversely, those for whom the source of truth was the unity of the three mental components - the mind, feelings and will - have not seen such a dichotomy. Philosophy, according to the first glance, operates on the principle of rationally proven truth or untruth, and literature - aesthetically aroused affect or quasi-truth, and according to the second - both philosophy and literature act by intuitively tangible truth. The language of philosophy, according to the first - is purely conceptual, and literature - emotional and figurative, and according to the second - equally Polesymic. The truth of the first is universal and extratextual, and the second is limited to the text» (Fizer, 1998, p. 101).

In our opinion, it is appropriate in this perspective to ask I. Fizer about what philosophy, in relation to literature, can be said. The scientist is convinced that «... in any case, not about analytically oriented philosophy, which focuses on universal timeless problems or a metasystem of logical syntax, but about a philosophy that focuses on man with his pains, joys, doubts, illogicalities - that is, with all the basic problems of human existence» (Fizer, 1990, p. 35). We would like to add that one of these philosophies, known as existentialism, was widely applied to literary texts in the 1940s and 1950s. It was considered genetically related to the literature.

Among philosophers, this philosophy found common thematic problems. «As a result, the formal and even genre features of philosophy and literature have become significantly blunted» (Sartre, 1973, p. 128). In addition to existentialism, literary texts resonate with Marxist and phenomenological philosophy. Of these three philosophical schools, the most comprehensive is the phenomenological, because it pays attention not only to the semantic but also to the linguistic aspect of literary texts. Basically, existential and Marxist philosophies are interested in the systematic delivery of the text, with the difference that the former focuses on the search for or absence of human authenticity, the absurdity of its existence, its alienation, its acute awareness of death, in the words of Jaspers - «borderline situations» her life. Without the 
purpose of the text of theological directives, explanations or fictions, this philosophy is thoroughly fatalistic. Instead, Marxist philosophy localizes such situations in a socioeconomic context and explains them either optimistically or pessimistically. Phenomenological philosophy, as a scientific discipline of claims and direction, does not have a final explanation of the text.

Ivan Fizer considers the relationship between the philosophy of Shevchenko's work according to M. Weitz's scheme, according to which such a relationship should be interpreted as three separate problems, namely: 1) philosophy and literature, 2) philosophy of literature and 3) philosophy in literature. In our opinion, this approach to this problem eliminates the undifferentiated nature of this relationship and at the same time provides clarity of presentation.

\section{PHILOSOPHY AND CREATIVITY OF SHEVCHENKO}

T. Shevchenko, like most prominent poets, did not systematically study philosophy, which, more than he wrote in his diary, he felt antipathy to it. «Despite my sincere love for beauty in art and in nature, I feel an irresistible antipathy for philosophers and aesthetics. And I owe this feeling first to Galich and finally to the most respected V.I.Grigorovich, who once read to us lectures on the theory of fine arts, the motto of which was: to talk more and criticize less. Purely Platonic maxim» (Shevchenko, 1964, p. 83).

I. Fizer is convinced that this antipathy does not mean that Shevchenko was not familiar with philosophy, on the contrary, to feel antipathy to something, you need to know it. According to I. Fizer, of the five branches of Shevchenko's academic philosophy, aesthetics was the most attractive, but he did not have a stable view of the aesthetic problems that dominated the thinking of that time. The American literary critic believes that 1) Shevchenko was an opponent of mysticism, which defended the supernatural and unexplained root cause of the phenomena of nature and existence in general; 2) he was against the idea of the primacy of spirit and the secondary nature of matter; 3) considered matter and spirit as equal and interdependent components of existence; 4) understood the «will and power of the spirit» as the immanent dynamics of being; 5) believed in the «truth as old as the world», that in the whole visible and invisible world there is an «omnipotent Creator of the universe»; 6) rejected the normative theory of art, which, from the standpoint of a priori canons, insisted on the rational regularity of the creative process; 7) believed in the exceptional, «endowed with the divine mind-senses» man-artist; 8) did not give priority to nature or art, but instead believed in their interaction; 9) believed that knowledge of art is possible on the basis of history, not theoretical aesthetics; 10) regarding the philosophy of Plato and Aristotle, Shevchenko's position is closer to the second than to the first. 
Fizer is convinced that not only his poetic genius, not only his polyhistorical curiosity, but also his unceasing relationship with the humanities turned him to a philosophical understanding of the problems of existence and human existence. He listened to lectures on art theory at the Academy of Arts, met and talked with prominent people, read Polish and French historians, knew Greek mythology and the Bible.

The main motive of Shevchenko's worldview was his anthropocentrism. D. Chizhevsky noted: «...with extreme pressure, always and everywhere puts a person in the center of the world, the world of nature and history» (Chizhevsky, 1960, p. 334).

\section{PHILOSOPHY OF SHEVCHENKO'S CREATIVITY}

According to I. Fizer, the philosophy of Shevchenko's work consists in the correspondence of poetic and conceptual truth. «The truth of Shevchenko is the truth of the calf (from the Greek telos), which not only represents, but at the same time defends the ethical transformation of all that levels the humanity of man. This is the truth with a deep belief in justice and the ideal state of affairs» (Fizer, 1990, p. 38). Shevchenko believed and dreamed of such interpersonal relations in Ukraine and in the world, in which there will be no enemy, but «there will be a son, and there will be a mother, and there will be people on earth». For him, as Ivan Franko claimed, truth was synonymous with just satisfaction Such a truth, Shevchenko believed, «must be, for the sun will rise and burn the defiled earth», and only such a truth, he told all people of good will, should we pray, and no longer worship anyone on earth.

According to I. Fizer, D. Chizhevsky is right when he claims that, putting man at the center of the world, nature and history, Shevchenko saw in the fate of his heroes «typically human destiny, human problems, relevant to his time. For social, political and ethical problems, Shevchenko knows only the language of living human images, he never, as is the case with other poets, he turns to the language of philosophical concepts and philosophical symbols» (Chizhevsky, 1960, p. 335).

\section{PHILOSOPHY IN SHEVCHENKO'S WORK}

The concept of «philosophy in literature» should be understood as two distinct, albeit closely related phenomena: a philosophical topic and a philosophical thesis. A literary work, according to I. Fizer, can have a theme without a thesis and vice versa, and can have both. The presence of the first, with sustained distancing of the author and a clear psychological and ideological differentiation of characters, makes the work polyphonic, while the presence of the second, as a clear ideological position not only the author but also the central character, makes it a work. 
The philosophical theme is seldom presented in the work in a special, technical language, but is mostly woven into the plot structure, character behavior, author's reflections and metatext; philosophical thesis in many cases is expressed by clearly defined statements.

Shevchenko's work - lyrical, epic, dramatic and prose - is very thematic. It contains love, domestic, historical, social, political, religious, philosophical themes. The latter do not act as a separate group, but are almost always intertwined with other topics. According to I. Fizer, they perform the function of either semantic accompaniment or the ideological frame of the text. In addition to conceptual themes, existing or coded, the literary critic distinguishes in Shevchenko's work two widely used concepts with frequent philosophical load. This is the concept of destiny and will. First, he, a convinced scientist, depending on the genre, plot and psychological aspects, used in three distinct semantic variants inherent in the Ukrainian language: 1) fate as a coincidence that is allegedly independent of human will; 2) destiny as a way of life and what arises on it; 3) destiny as a desirable, happy life. The second concept, also depending on these aspects: 1) will as freedom and independence; 2) will as the opposite of «captivity»; 3) will as desire.

If we consider the high activity of these two concepts (the first is used in Shevchenko's texts 208 times, and the second 129), says I. Fizer, we can not assume that the problem of causal conditionality of human existence, on the one hand, and the simultaneous absence of such conditionality, on the other hand, was not central to his worldview. «There is neither a positive nor an idealistic orientation in his work. Instead, there is a dialectical oscillation between two contradictory poles of human life: causal conditionality and freedom (or destiny and will)» (Fizer, 1998, p. 450).

Thus, I. Fizer believes that there is no philosophy as a systematic study of metaphysical, historiosophical, ethical and aesthetic problems in Shevchenko's literary heritage. However, some of his statements on these issues indicate a broad erudition of philosophy as a science. And his legacy, full of great love for wisdom and truth, has outgrown its purely aesthetic dimensions and become part of the national and universal system of values.

I would like to emphasize that «building a space of Ukrainian literary criticism can and should go not only in terms of circles, but also in different ways (in particular methodological ones), and what are their roads, the more - the better, the main thing - is to concentrate efforts on texts (writing, publication, discussion ), rather than on destructive contexts» (Chobanyuk, 2019, p. 152). 


\section{СПИСОК ЛІТЕРАТУРИ}

Сартр, Д. (1973). Экзистенциализм и современная литература. Москва,: «Академия».

Фізер, І. (1990). Філософія чи філо-софія Тараса Шевченка? Слово $i$ Час. № $5,33-41$.

Фізер, I. (1998). Естетика Шевченка. Сучасність, №5, 100 - 104.

Чижевський, Д. (1960). Шевченко і релігія. Повне видання творів Т. Г. Шевченка, Чикаго, Т. 9.

Чобанюк, М. (2019). Співвідношення мистецтва слова та науки як літературознавчий синтез. Рідне слово в етнокультурному вимірі: зб. наук. праць. Дрогобич: Посвіт, $151-157$.

Шевченко, Т. (1964). Повне зібр. творів: [в 5-томах]. Київ. Т. 5.

\section{REFERENCES}

Sartr, D. (1973). Ekzistentsializm i sovremennaya literatura. [Existentialism and Contemporary Literature]. Moscow. [in Russian]

Fizer, I. (1990). Filosofiya chy filo-sofiya Tarasa Shevchenka? [Philosophy or philosophy of Taras Shevchenko?]. Slovo i Chas - Word and Time. [in Ukrainian]

Fizer, I. (1998). Estetyka Shevchenka [Aesthetics of Shevchenko]. Suchasnist ${ }^{\prime}-$ Modernit, 5, 100 - 104. [in Ukrainian]

Chyzhevskyy, D. (1960). Shevchenko i relihiya [Shevchenko and religion]. Chykaho. [in Ukrainian]

Chobanyuk, M. (2019). Spivvidnoshennya mystetstva slova ta nauky yak literaturoznavchyy syntez. [The relationship between the art of speech and science as a literary synthesis]. Ridne slovo v etnokul'turnomu vymiri: zb. nauk. prats - Native word in the ethnocultural dimension: Coll. Sciense. Drohobych, Posvit. $151-157$. [in English]

Shevchenko, T. (1964). Povne zibr. tvoriv: [v 5-tomakh]. [Complete collection. works: [in 5 volumes]. Kyiv. T. 5. [in Ukrainian] 